Sains Malaysiana 49(4)(2020): 775-784

http://dx.doi.org/10.17576/jsm-2020-4904-06

\title{
Prodigiosin Serratia marcescens Tidak Bersifat Toksik terhadap Caenorhabditis elegans
}

(Serratia marcescens Prodigiosin is Non-toxic towards Caenorhabditis elegans)

\author{
Siew-Wei Seah, Nur Siti Fatimah Mohamad Jamil, Yann-Yin Lee, Cin Kong, Sheila Nathan \& Kiew-Lian \\ WAN*
}

\begin{abstract}
ABSTRAK
Produk semula jadi mikrob adalah sumber molekul yang berpotensi tinggi untuk penemuan dadah. Prodigiosin iaitu pigmen merah yang dihasilkan oleh Serratia marcescens, ialah calon dadah semula jadi kerana telah dilaporkan mempunyai sifat antimikrob, antimalaria dan antikanser. Dalam kajian ini, kami telah menilai ketoksikan prodigiosin dengan menggunakan nematod Caenorhabditis elegans, satu model perumah yang sering digunakan untuk menilai kepatogenan agen berjangkit dan ketoksikan produk semula jadi. Untuk menilai ketoksikan prodigiosin, C. elegans dijangkiti dengan strain penghasil prodigiosin, S. marcescens Bizio ATCC 274 (Sma 274) dan strain bukan penghasil, S. marcescens Bizio ATCC 29635 (Sma WF). Asai kemandirian telah dijalankan di bawah keadaan yang memastikan penghasilan prodigiosin pada tahap optimum. Menariknya, kinetik pembunuhan nematod oleh strain S. marcescens yang berpigmen dan tidak berpigmen tidak menunjukkan perbezaan yang ketara (Log-rank (Mantel-Cox) test, p>0.0001), dan ini mencadangkan bahawa prodigiosin bukanlah molekul yang toksik. Seterusnya, C. elegans dirawat terus dengan prodigiosin tanpa kehadiran S. marcescens dan ketoksikan prodigiosin terhadap nematod telah dinilai. Tiada pengurangan kadar kemandirian yang signifikan diperhatikan apabila C. elegans diberikan ekstrak prodigiosin jika dibandingkan dengan kawalan yang tidak dirawat (Log-rank (Mantel-Cox) test, p>0.0001). Hasil ini membuktikan bahawa prodigiosin tidak memberi sebarang kesan toksik terhadap cacing nematod dewasa. Kesimpulannya, prodigiosin S. marcescens adalah tidak toksik terhadap perumah C. elegans, dan ini membuka peluang untuk penyelidikan tentang prodigiosin sebagai dadah farmaseutis.
\end{abstract}

Kata kunci: Dadah semula jadi; ketoksikan; pigmen bakteria

\section{ABSTRACT}

Microbial natural products are a promising source of molecules for drug discovery. Prodigiosin, a red microbial pigment produced by Serratia marcescens, is a promising natural drug candidate due to its reported antimicrobial, antimalarial and anticancer properties. In this study, we evaluated the toxicity of prodigiosin by using the nematode Caenorhabditis elegans, a host model frequently used to evaluate pathogenicity of infectious agents and toxicity of natural products. To investigate the toxicity of prodigiosin, C. elegans was infected with the prodigiosin-producer $\mathrm{S}$. marcescens Bizio ATCC 274 (Sma 274) and non-prodigiosin producer S. marcescens Bizio ATCC 29635 (Sma WF). The survival assay was performed under conditions that ensure optimal prodigiosin production. Intriguingly, the nematode killing kinetics did not differ significantly between the pigmented and non-pigmented $\mathrm{S}$. marcescens strains (Log-rank (Mantel-Cox) test, $p>0.0001$ ), indicating that prodigiosin is not a toxic molecule. Subsequently, C. elegans were treated directly with prodigiosin in the absence of $\mathrm{S}$. marcesccens and prodigiosin toxicity on the worms was assessed. No significant decrease in survival was observed when C. elegans was treated with prodigiosin extract compared to the untreated control (Log-rank (Mantel-Cox) test, $p>0.0001$ ), indicating that prodigiosin does not exert any toxic effect on adult worms. In conclusion, S. marcescens prodigiosin is non-toxic towards the C. elegans host, thus, opening up avenues for research on prodigiosin as a pharmaceutical drugstudied.

Keywords: Bacterial pigment; natural drug; toxicity

\section{PENDAhULUAN}

Penemuan dan pembangunan dadah baru dalam industri farmaseutik sering berasaskan dadah sintetik dan usaha ini telah berjaya memerangi pelbagai jenis penyakit. Namun begitu, penghasilan dadah sintetik melibatkan pelbagai langkah sintesis organik yang memerlukan tenaga kerja yang tinggi dan sumber yang banyak (Webb \& Jamison 2010). Di samping itu, dadah sintetik sering menyebabkan kesan sampingan. Produk yang dihasilkan secara semula jadi berpotensi untuk dibangunkan sebagai alternatif yang mampan (Harvey 2008; Koehn \& Carter 2005).

Prodigiosin, sejenis pigmen merah yang dihasilkan oleh bakteria Serratia marcescens, merupakan produk semula jadi yang dianggap sebagai dadah farmaseutik yang berpotensi tinggi kerana ia mempunyai aktiviti antimikrob, antimalaria dan antikanser (Yip et al. 2019). 
Namun begitu, maklumat yang menyokong prodigiosin sebagai sebatian yang selamat untuk digunakan adalah terhad. Prodigiosin didapati berupaya membunuh sel kanser secara selektif tanpa menjejaskan sel normal (Deorukhkar et al. 2007; Kavitha et al. 2010). Selain itu, kajian yang dilaporkan oleh Guryanov et al. (2013) telah menunjukkan bahawa prodigiosin bukan bersifat genotoksik. Oleh itu, prodigiosin boleh dikembangkan sebagai dadah farmaseutik yang berpotensi. Walau bagaimanapun, penilaian lanjut ketoksikan prodigiosin perlu dilakukan bagi memperluaskan kegunaannya dalam industri farmaseutik.

Dalam kajian ini, penilaian ketoksikan prodigiosin dijalankan dengan menggunakan haiwan perumah model, cacing nematod Caenorhabditis elegans yang membolehkan penilaian ketoksikan dadah secara awal dilakukan. Kelebihan model C. elegans adalah ia mempunyai tapak jalan keimunan inat yang terpelihara dalam mamalia (Kong et al. 2016). Selain itu, hasil kajian dengan menggunakan cacing nematod model ini boleh diperpanjangkan kepada organisma yang lebih kompleks, termasuk manusia (Irazoqui et al. 2010). Tambahan pula, beberapa kajian telah dijalankan untuk mencirikan interaksi patogen dan perumah antara $S$. marcescens dan C. elegans (Kurz et al. 2003; Pradel et al. 2007; Wilf \& Salmond 2012). Dalam kajian ini, asai kemandirian telah dilakukan menggunakan C. elegans yang diinfeksi secara berasingan dengan $S$. marcescens Bizio ATCC 274 (Sma 274) yang mampu menghasilkan prodigiosin dan S. marcescens Bizio ATCC 29635 (Sma WF) yang tidak berkebolehan menghasilkan prodigiosin. Penghasilan prodigiosin dioptimumkan terhadap parameter persekitaran seperti medium, $\mathrm{pH}$ dan suhu yang berbeza. Pengasaian kemandirian seterusnya dijalankan di bawah keadaan yang optimum yang membolehkan penghasilan prodigiosin pada aras yang tinggi. Di samping itu, ujian ketoksikan juga dijalankan menggunakan $C$. elegans yang dirawat terus dengan prodigiosin tanpa kehadiran $S$. marcescens. Hasil penilaian ketoksikan ini boleh membantu dalam mengukuhkan lagi nilai terapeutik prodigiosin.

\section{BAHAN DAN KAEDAH}

\section{STRAIN BAKTERIA DAN NEMATOD}

Bakteria S. marcescens Sma 274 yang berupaya menghasilkan prodigiosin dan Sma WF yang tidak menghasilkan prodigiosin diperoleh daripada Pusat Sumber Biologi American Type Culture Collection. Bakteria Sma 274 dan Sma WF masing-masing dikultur pada agar nutrien (NA) dan agar infusi jantung otak (BHIA) pada suhu $26^{\circ} \mathrm{C}$. Pengkulturan Escherichia coli OP50 dilakukan dalam kaldu Luria-Bertani (LB) yang mengandungi $100 \mu \mathrm{g} / \mathrm{mL}$ antibiotik Streptomisin pada suhu $37^{\circ} \mathrm{C}$ secara goncangan semalaman.

Strain mutan C. elegans glp-4 yang digunakan dalam kajian ini diperoleh daripada Caenorhabditis Genetics Center, University of Minnesota, USA. Cacing nematod ini dipelihara di atas medium pertumbuhan nematod (NGM) pada suhu $16{ }^{\circ} \mathrm{C}$ dengan bakteria $E$. coli OP50 sebagai sumber makanan. Untuk memperoleh populasi nematod yang berada pada peringkat umur yang sama, sinkronisasi dilakukan melalui kaedah 'egg prep' seperti yang dijelaskan oleh Shapira dan Tan (2008). Ini dilakukan dengan menggunakan larutan lisis yang mengandungi hipoklorit beralkali dan natrium hidroksida. Telur yang diperoleh daripada C. elegans dewasa diletakkan di atas piring agar NGM baru yang mengandungi E. coli OP50 dan $100 \mu \mathrm{g} / \mathrm{mL}$ streptomisin. Piring agar tersebut dieram pada suhu $25{ }^{\circ} \mathrm{C}$ selama tiga hari untuk memperoleh C. elegans pada peringkat dewasa.

\section{PENGOPTIMUMAN KEADAAN PENGKULTURAN BAGI PENGHASILAN PRODIGIOSIN}

Tiga parameter pertumbuhan yang berbeza iaitu jenis medium, suhu dan $\mathrm{pH}$ dinilai secara bertahap untuk menentukan keadaan pengkulturan yang memastikan penghasilan prodigiosin yang tinggi. Jenis medium yang sesuai ditentukan terlebih dahulu, diikuti dengan penentuan suhu dan $\mathrm{pH}$. Sma WF yang tidak berupaya menghasilkan prodigiosin digunakan sebagai kawalan negatif dalam ujian penentuan ini. Sma 274 dan Sma WF dieram dengan goncangan untuk semalaman pada suhu $37{ }^{\circ} \mathrm{C}$ masing-masing dalam kaldu nutrien (NB) dan kaldu infusi jantung otak (BHIB). Bilangan sel bakteria dalam kultur semalaman Sma 274 dan Sma WF dilaraskan kepada kira-kira $108 \mathrm{CFU} / \mathrm{mL}$ dan pencairan 1:100 dilakukan untuk semua asai yang berikutnya. Kultur Sma 274 dan Sma WF yang telah dicairkan masingmasing ditumbuh dalam NB dan kaldu pepton gliserol (PGB) pada suhu $28^{\circ} \mathrm{C}$ selama 48 jam. Penghasilan prodigiosin oleh Sma 274 di dalam medium M9 dan PGB juga diperhatikan dan dibandingkan secara kuantitatif. Penghasilan prodigiosin dalam kaldu dianalisis secara spektrofotometri (NanoDrop 2000c, Thermo Fisher Scientific Inc., USA). Untuk menentukan jumlah prodigiosin yang terhasil (unit per sel bakteria) dalam setiap kaldu di bawah keadaan piawai, rumusan terbitan Haddix and Werner (2000) berikut digunakan:

$$
\text { Prodigiosin }(\underline{\text { unit }})=\left[\mathrm{OD}_{499}-\left(1.382 \times \mathrm{OD}_{620}\right)\right] \times 1000
$$

dengan OD499 sedalah nilai penyerapan prodigiosin; OD620 adalah nilai penyerapan bakteria; dan 1.381 adalah pemalar.

Jenis agar dan jenis kaldu yang lebih mendorong penghasilan prodigiosin ditentukan dan kemudiannya digunakan dalam ujian penentuan kesan suhu. Keduadua kultur Sma 274 dan Sma WF yang telah dicairkan kepada $108 \mathrm{CFU} / \mathrm{mL}$ dieram dalam medium pengkulturan terpilih masing-masing pada suhu $20^{\circ} \mathrm{C}, 25^{\circ} \mathrm{C}, 28^{\circ} \mathrm{C}, 32$ ${ }^{\circ} \mathrm{C}$ atau $37{ }^{\circ} \mathrm{C}$ selama 48 jam. Seterusnya, jenis medium 
dan suhu eraman yang lebih mendorong penghasilan prodigiosin digunakan dalam ujian penentuan kesan $\mathrm{pH}$. Medium pengkulturan terpilih pada $\mathrm{pH}$ 5, 6, 7, 8 atau 9 digunakan untuk mengenal pasti keadaan yang berupaya menghasilkan jumlah prodigiosin tertinggi.

\section{ASAI KEMANDIRIAN C. elegans}

Asai kemandirian berasaskan cecair dilakukan berdasarkan Kong et al. (2014) dengan beberapa pengubahsuaian berdasarkan keadaan teroptimum untuk menghasilkan jumlah prodigiosin tertinggi. Terdapat tiga jenis rawatan dalam pengasaian ini iaitu C. elegans yang diinfeksi Sma 274, C. elegans yang diinfeksi Sma WF dan C. elegans yang diberi makanan ruji $E$. coli OP50 sebagai kawalan tanpa infeksi. Medium untuk pengasaian kemandirian (90\% PGB pH 7, $10 \mu \mathrm{g} / \mathrm{mL}$ kolesterol dan 10\% kultur semalaman Sma 274 atau Sma WF) ditambah ke dalam setiap telaga $(500 \mu \mathrm{L})$ pada piring 24-telaga. Dalam telaga kawalan, bakteria $S$. marcescens dan medium PGB masing-masing digantikan dengan E. coli OP50 dan medium minima M9. Setiap rawatan diuji dalam tiga replikat teknikal. Pengasaian kemandirian bermula apabila 20 mutan $C$. elegans glp-4 dewasa dipindahkan ke dalam setiap telaga dan dieram pada suhu $28^{\circ} \mathrm{C}$. Pemerhatian dilakukan setiap 24 jam untuk menentukan bilangan $\mathrm{C}$. elegans yang hidup dan mati sehingga kesemua cacing nematod yang diinfeksi telah mati. Menurut Tan et al. (1999), C. elegans yang tidak menunjukkan pengepaman farinks dan tidak bergerak balas terhadap sentuhan wayar platinum dianggap telah mati. Cacing nematod yang mati akibat vulva yang pecah dikecualikan daripada analisis pengasaian.

\section{ASAI KETOKSIKAN PRODIGIOSIN}

Penyediaan ekstrak prodigiosin telah dijalankan mengikut kaedah Nakashima et al. (2005) dengan sedikit pengubahsuaian. Secara ringkasnya, Sma 274 dikultur dalam $100 \mathrm{~mL}$ medium PGB pada $\mathrm{pH} 7$ dan dieram pada suhu $28{ }^{\circ} \mathrm{C}$ selama 48 jam untuk mencapai amaun prodigiosin yang tinggi. Kultur bakteria tersebut diempar pada $10000 \times$ g selama $10 \mathrm{~min}$. Supernatan disingkirkan dan pelet yang tertinggal dalam tiub emparan diampaikan dengan jumlah isi padu metanol $95 \%$ yang sama. Kemudian campuran ini divortek dan diempar sekali lagi pada 10000 $\times$ g selama 30 min untuk menyingkirkan sebarang bahan yang tidak larut. Supernatan kemudiannya dipindah ke tiub emparan yang baru. Sebanyak $1 \mathrm{~mL}$ supernatan hasil pengekstrakan prodigiosin dipindah ke kuvet dan diukur secara spektrofotometri pada panjang gelombang penyerapan antara $250 \mathrm{~nm}$ ke $700 \mathrm{~nm}$ (Allen 1967). Profil penyerapan dicatat dan digunakan untuk mengenal pasti kehadiran prodigiosin dalam supernatan tersebut. Supernatan prodigiosin yang tertinggal kemudiannya dikeringkan di bawah vakum dan amaun pigmen yang diperoleh ditentukan berdasarkan berat keringnya. Sisa kering kemudiannya dilarut dalam 95\% metanol dan kepekatannya ditentukan dalam $\mathrm{mg} / \mathrm{mL}$.

Dalam asai ketoksikan ini, dua jenis medium disediakan iaitu medium rawatan yang mengandungi ekstrak prodigiosin dan medium kawalan negatif tanpa ekstrak prodigiosin. Asai ketoksikan ini dilakukan dengan menggunakan medium M9 iaitu sejenis larutan garam seimbang yang lazim digunakan untuk $C$. elegans dalam asai ketoksikan (Kong et al. 2014). Medium rawatan terdiri daripada $90 \%$ medium M9, 10\% E. coli OP50 yang telah mati, $10 \mu \mathrm{g} / \mathrm{mL}$ kolesterol dan $400 \mu \mathrm{g} / \mathrm{mL}$ ekstrak prodigiosin manakala bagi medium kawalan negatif, ekstrak prodigiosin digantikan dengan metanol $95 \%$. Kepekatan ekstrak yang digunakan bagi pengasaian ini ditetapkan berdasarkan kajian penyaringan aktiviti antimikrob prodigiosin yang telah dilakukan sebelum ini (Nur Siti Fatimah, data belum diterbitkan). Medium rawatan dan medium kawalan negatif masing-masing ditambahkan ke dalam telaga pada piring 24-telaga. Bakteria E. coli OP50 telah dibunuh dengan haba pada suhu $65^{\circ} \mathrm{C}$ selama 30 minit sebelum ditambah ke dalam setiap telaga sebagai sumber makanan untuk cacing nematod. Pembunuhan E. coli OP50 ini dilakukan untuk menyingkirkan sebarang kesan ekstrak terhadap E. coli hidup yang mungkin menjejas keberkesanan eksperimen memandangkan asai ini hanya menumpu pada kesan prodigiosin terhadap jangka hayat cacing. Sebanyak 10 C. elegans mutan $g l p-4$ dewasa dipindahkan ke dalam setiap telaga dan piring tersebut dieram pada suhu $25^{\circ} \mathrm{C}$. Setiap rawatan diuji dalam tiga replikat teknikal. Bilangan C. elegans yang hidup dan mati dalam setiap telaga ditentukan setiap hari sehingga kesemua cacing nematod mati. Cacing nematod yang mati akibat vulva yang pecah dikecualikan daripada analisis pengasaian ini. Data kemudian dianalisis dan lengkung kemandirian diplotkan untuk membandingkan antara rawatan dan kawalan.

\section{ANALISA STATISTIK}

Hasil daripada ujian pengoptimuman penghasilan prodigiosin dianalisis dengan ujian statistik $\mathrm{t}$ (independent sample t-test). Data yang diperoleh mewakili purata jumlah prodigiosin terhasil dan sisihan piawai (SD) yang dijana daripada tiga set replikat. Analisis kemandirian Kaplan-Meier yang terdapat dalam perisian StatView ${ }^{\circledR}$ 5.0.1 telah digunakan untuk menganalisis hasil asai kemandirian dan asai ketoksikan untuk mendapatkan nilai TDmin, iaitu min masa yang diperlu untuk membunuh 50\% populasi cacing nematod (Alegado et al. 2003). Selepas itu, perbandingan dilakukan antara kumpulan kawalan dan rawatan dengan ujian statistik Log-rank (Mantel-Cox). Data daripada pengasaian dinyatakan sebagai SD yang dijana daripada sekurang-kurang dua set replikat. 
HASIL

\section{KEADAAN PENGKULTURAN PENGHASILAN PRODIGIOSIN TINGGI}

Kepatogenan sesuatu spesies bakteria dipengaruhi oleh keadaan persekitaran yang tertentu. Bakteria yang dikultur dalam medium yang berbeza boleh mempamerkan kepatogenan yang berbeza (Garsin et al. 2001). Misalnya, medium yang kaya dengan nutrien dapat mendorong bakteria mengekspres faktor-faktor virulen yang berupaya membunuh $C$. elegans berbanding medium pertumbuhan nematod yang biasa digunakan (Garsin et al. 2001). Oleh itu, kami berminat untuk mengkaji kepatogenan $S$. marcescens Sma 274 dan Sma WF terhadap C. elegans apabila bakteria ini dieram di dalam keadaan optimum yang menghasilkan jumlah prodigiosin yang tinggi.

Sebelum menguji sifat ketoksikan prodigiosin ke atas nematod, keadaan optimum in vitro bagi penghasilan prodigiosin daripada Sma 274 telah ditentukan. Ini membantu memberi gambaran tentang kevirulenan prodigiosin $S$. marcescens dalam medium kaya-nutrien. Dalam kajian ini, penghasilan prodigiosin yang signifikan $(\mathrm{p}<0.05)$ diperhatikan oleh bakteria yang dikultur dalam medium PGB (664 \pm 32.26 unit/sel) berbanding dengan NB (546.0 \pm 26.17 unit/sel) oleh Sma 274 (Rajah 1A). Justeru, PGB telah dipilih sebagai medium pengkulturan untuk kajian pengoptimuman selanjutnya. Penghasilan prodigiosin yang signifikan $(\mathrm{p}<0.05)$ juga diperhatikan apabila bakteria dikultur dalam medium PGB pada suhu $28{ }^{\circ} \mathrm{C}(683.1 \pm 4.1 \mathrm{unit} / \mathrm{sel})$ berbanding dengan $20^{\circ} \mathrm{C}$ (571.1 \pm 12.7 unit/sel), $25{ }^{\circ} \mathrm{C}(581.9 \pm 22.7$ unit/sel $), 32$ ${ }^{\circ} \mathrm{C}(562.8 \pm 25.5$ unit/sel $)$ dan $37^{\circ} \mathrm{C}(274.1 \pm 44.0$ unit/ sel) (Rajah 1B). Nilai purata prodigiosin yang dihasilkan adalah lebih tinggi $(\mathrm{p}<0.05)$ apabila Sma 274 dikultur dalam PGB pada $\mathrm{pH} 7$ (596.5 \pm 13.6 unit/sel) berbanding dengan $\mathrm{pH} 8(566.7 \pm 6.4 \mathrm{unit} / \mathrm{sel}), \mathrm{pH} 9(317.1 \pm 29.3$ unit/sel), pH 6 (300.0 \pm 41.9 unit/sel) dan pH 5 (273.2 \pm 8.8 unit/sel) (Rajah 1C). Tiada penukaran warna diperhatikan untuk koloni Sma WF sepanjang semua ujian pengoptimuman berbanding dengan koloni Sma 274 yang berwarna merah (Rajah 1D) menunjukkan tiada prodigiosin dihasilkan oleh strain mutan tersebut.

\section{PENGEKSTRAKAN PRODIGIOSIN}

Proses pengekstrakan prodigiosin telah dilakukan dan hasil pengekstrakan telah dianalisis melalui kaedah spektrofotometri. Berdasarkan de Araujo et al. (2010), prodigiosin yang diekstrak dilaporkan mempunyai penyerapan maksimum pada panjang gelombang di antara $535 \mathrm{~nm}$ dan $540 \mathrm{~nm}$. Dalam kajian ini, satu puncak yang jelas telah diperhatikan pada jarak gelombang $535 \mathrm{~nm}$ pada profil penyerapan sampel yang diekstrak daripada Sma 274 (Rajah 2A). Ini menunjukkan bahawa sampel yang diekstrak mengandungi prodigiosin. Sebaliknya, profil penyerapan sampel yang diekstrak daripada Sma
WF tidak menunjukkan sebarang puncak yang ketara di antara panjang gelombang $535 \mathrm{~nm}$ dan $540 \mathrm{~nm}$ (Rajah 2B) dan ini mengesahkan bahawa tiada prodigiosin hadir dalam ekstrak sampel Sma WF yang memang diketahui tidak menghasilkan prodigiosin.

\section{KESAN PRODIGIOSIN TERHADAP KADAR KEMANDIRIAN C. elegans}

Menurut kajian terdahulu, bakteria $S$. marcescens berupaya untuk membunuh $C$. elegans melalui proses kolonisasi usus (Mallo et al. 2002). Oleh itu, sistem model $S$. marcescens-C. elegans telah mencadangkan beberapa faktor kevirulenan termasuk protein yang terlibat dalam proses pengambilan ferum dan penghasilan hemolisin yang berpotensi mempengaruhi kepatogenan bakteria (Kurz et al. 2003). Dalam kajian ini, kegunaan model C. elegans telah diperluaskan untuk mengenal pasti ketoksikan prodigiosin kerana penggunaan model haiwan seperti $C$. elegans boleh membekalkan maklumat mengenai organisma hidup yang lengkap dengan sistem penghadaman, pembiakan, endokrin dan deria (Hunt 2017). Secara lazimnya, medium M9 sering digunakan dalam asai kemandirian cecair dan asai jangka hayat $C$. elegans (Bansal et al. 2015; Eng \& Nathan 2015; Kong et al. 2014). Namun demikian, dalam kajian ini penghasilan prodigiosin pada aras tinggi adalah optimum dalam medium PGB. Maka, untuk menunjukkan kesesuaian PGB sebagai medium untuk asai kemandirian cecair, penghasilan prodigiosin oleh Sma 274 dan Sma WF yang dikultur dalam medium PGB dan M9 telah dibandingkan (Rajah 3). Didapati bahawa Sma 274 dan Sma WF tidak dapat tumbuh dengan baik dalam medium M9 (Rajah 3C dan 3D). Hasil kajian juga menunjukkan Sma 274 tidak dapat menghasilkan jumlah prodigiosin yang optimum dalam medium M9 berbanding PGB (Rajah 4A). Penghasilan prodigiosin didapati adalah lebih 3-kali ganda $(\mathrm{p}<0.05)$ apabila Sma 274 dikultur dalam PGB (380.1 \pm 26.8 unit/sel) berbanding dengan medium M9 (120.2 \pm 13.7 unit/sel) (Rajah 4B). Oleh itu, PGB dicadangkan sebagai medium yang lebih sesuai untuk digunakan untuk asai kemandirian $C$. elegans di bawah keadaan penghasilan prodigiosin yang tinggi.

Untuk menentukan sama ada prodigiosin memainkan peranan dalam kevirulenan bakteria, C. elegans dijangkiti dengan dua strain $S$. marcescens yang berbeza di bawah keadaan penghasilan prodigiosin optimum iaitu menggunakan PGB pada pH 7.0 dan dieram pada $28^{\circ} \mathrm{C}$. Rajah 4C menunjukkan graf pengasaian kemandirian bagi kedua-dua rawatan dan kawalan. Cacing nematod yang diberi E. coli OP50 sebagai makanan tetap bermandiri sepanjang masa kajian. Nilai $\mathrm{TD}_{\min }$ iaitu min masa untuk membunuh C. elegans oleh Sma 274 adalah lebih pendek berbanding dengan Sma WF, iaitu masingmasing $33.281 \pm 2.182$ jam dan $41.683 \pm 2.513$ jam (Jadual 1). Walau bagaimanapun, dalam ujian statistik Log-rank (Mantel-Cox) pula, nilai P yang diperoleh adalah lebih 
daripada 0.0001 menunjukkan perbezaan min masa membunuh nematod antara Sma 274 dan Sma WF adalah tidak signifikan (Jadual 1). Hasil ini mencadangkan dinamik pembunuhan cacing nematod dewasa muda oleh Sma 274 tidak berbeza secara ketara dengan Sma WF walaupun Sma 274 merembeskan amaun prodigiosin yang tinggi. Ini mencadangkan bahawa prodigiosin tidak mempunyai kesan negatif terhadap kemandirian $C$. elegans. Oleh itu, prodigiosin bukanlah molekul toksik walaupun terhasil pada amaun yang tinggi oleh Sma 274 yang dikulturkan di bawah keadaan optimum.

Asai ketoksikan cacing nematod dengan kehadiran atau ketiadaan ekstrak prodigiosin telah mengesahkan ketidaktoksikan sebatian ini terhadap cacing nematod. C. elegans dewasa telah diperhatikan di bawah stereomikroskop dengan kuasa pembesaran yang tinggi (200X) untuk mengesahkan lokasi prodigiosin di dalam organisma tersebut (Rajah 5A). Keseluruhan farinks dan usus $C$. elegans yang dirawat dengan prodigiosin berwarna merah berbanding dengan $C$. elegans kawalan metanol 95\% yang tidak berwarna. Pemerhatian ini menunjukkan bahawa $C$. elegans telah terdedah kepada prodigiosin sepenuhnya. Lengkung kemandirian yang diplot untuk kedua-dua kawalan dan rawatan menunjukkan profil yang sama (Rajah 5B). Min jangka hayat yang dihitung bagi $C$. elegans kawalan dan diberi ekstrak adalah masing-masing sepanjang $387.93 \pm 11.85$ jam dan $395.33 \pm 13.08$ jam, atau lebih kurang 16 hari. Ujian Log-rank (Mantel-Cox) untuk membandingkan min jangka hayat cacing kawalan dan terawat memberikan nilai P 0.9332 . Oleh kerana min jangka hayat kedua-dua cacing kawalan dan rawatan tidak berbeza secara signifikan, maka, boleh disahkan bahawa prodigiosin adalah metabolit sekunder bakteria S. marcescens yang tidak toksik.
A

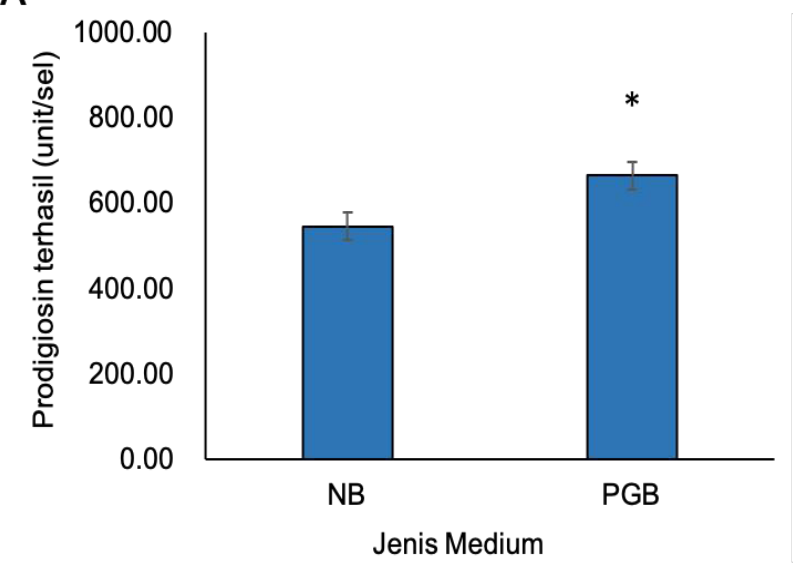

B

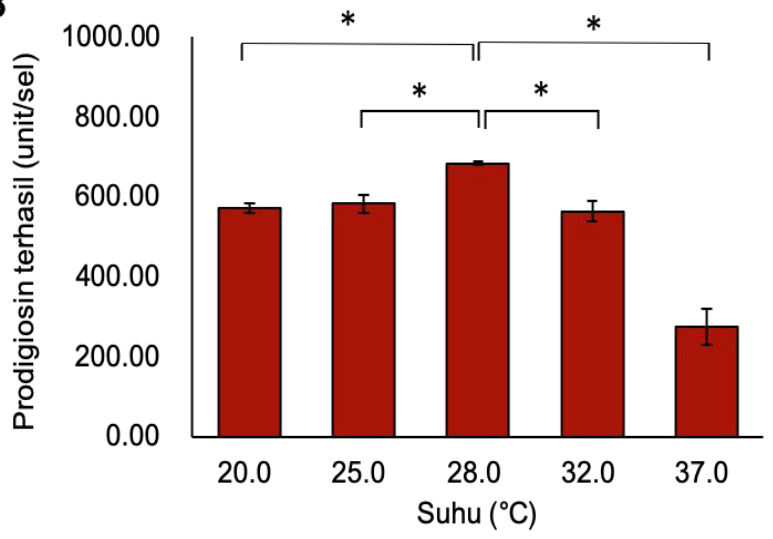

C

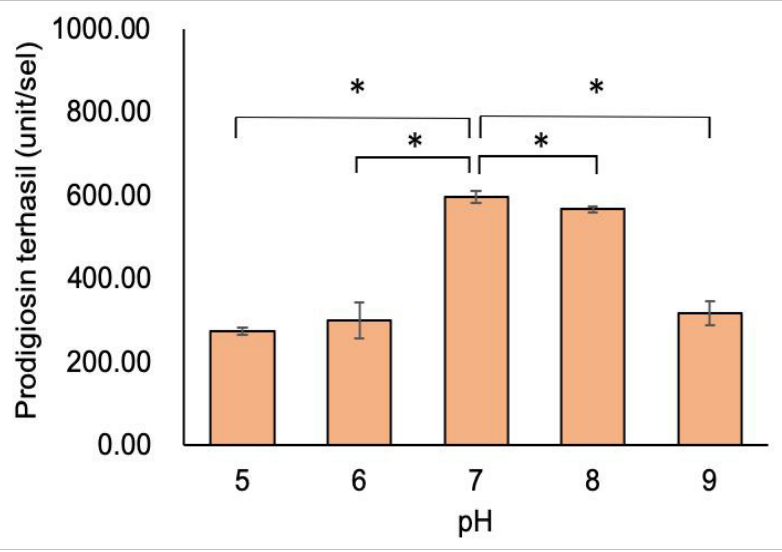

D

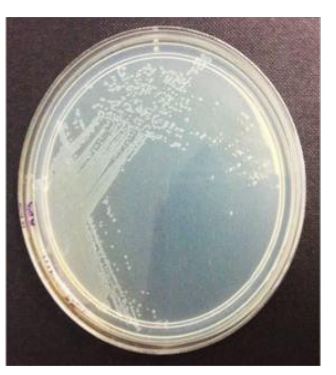

Sma WF

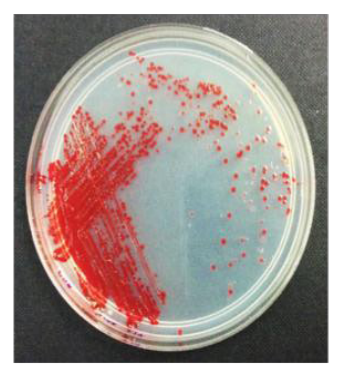

Sma 274

RAJAH 1. Pengoptimuman penghasilan prodigiosin Sma 274 dan Sma WF pada parameter yang berlainan

Kesan (A) jenis medium, (B) suhu dan (C) pH terhadap penghasilan prodigiosin Sma 274. Kesan terhadap suhu dan pH telah dilakukan dalam medium pengkulturan PGB. (D) Fenotip kawalan negatif S. marcescens Sma WF sepanjang semua ujian pengoptimuman berbanding dengan fenotip Sma 274. Setiap bar mewakili purata jumlah prodigiosin terhasil dan sisihan piawai yang dijana daripada tiga set replikat. Tanda asterik $(*)$ menunjukkan perbezaan signifikan pada tahap $\mathrm{p}<0.05$, berdasarkan kepada ujian statistik t. 
A

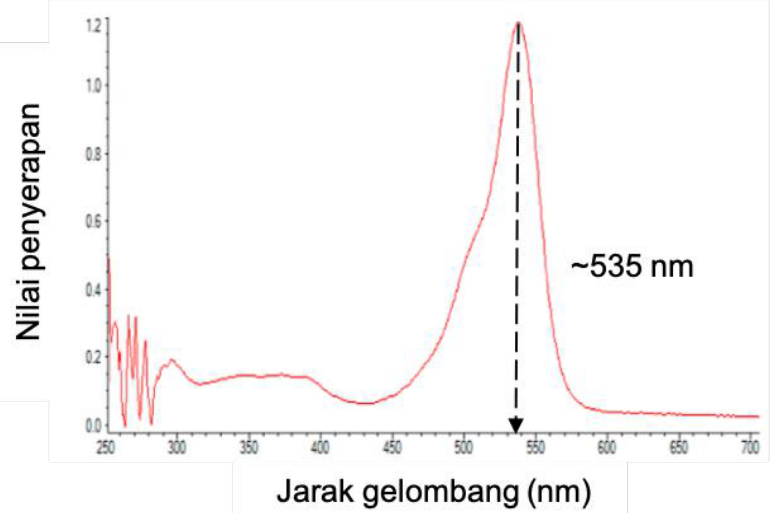

B

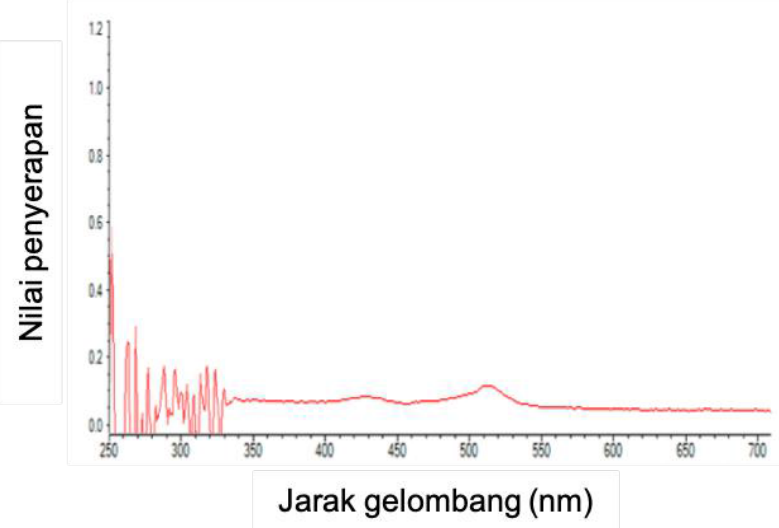

RAJAH 2. Profil penyerapan hasil pengekstrakan daripada S. marcescens pada jarak gelombang $250 \mathrm{~nm}$ ke $700 \mathrm{~nm}$ Hasil pengekstrakan daripada kaldu pengkulturan (A) Sma 274 dan (B) Sma WF

\section{Medium PGB}

A

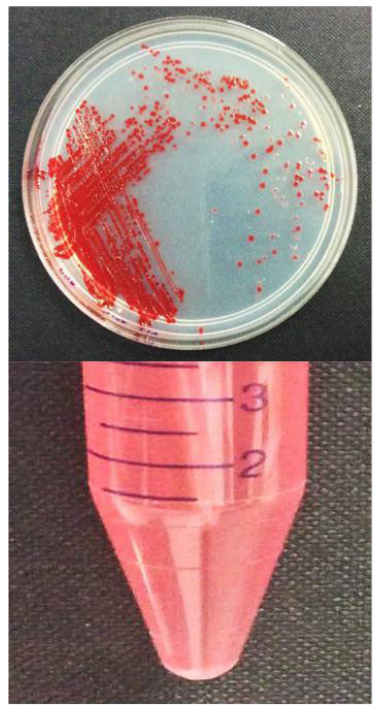

B

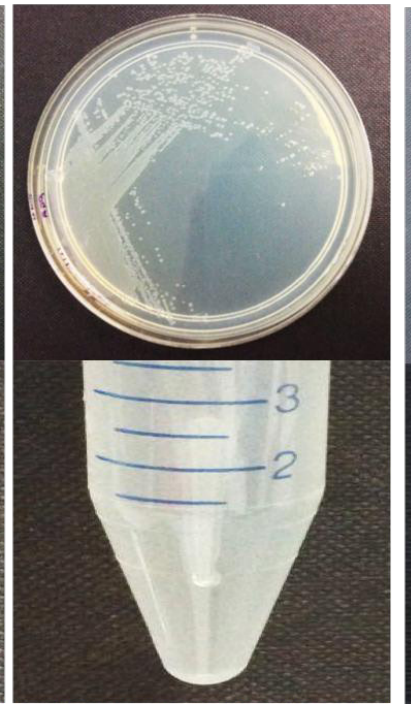

Medium M9

C

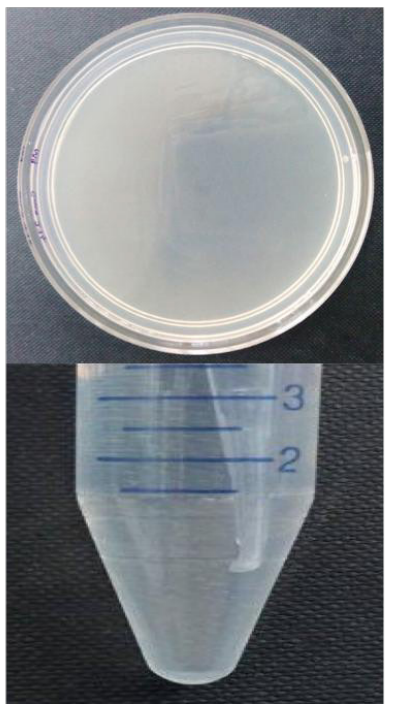

D

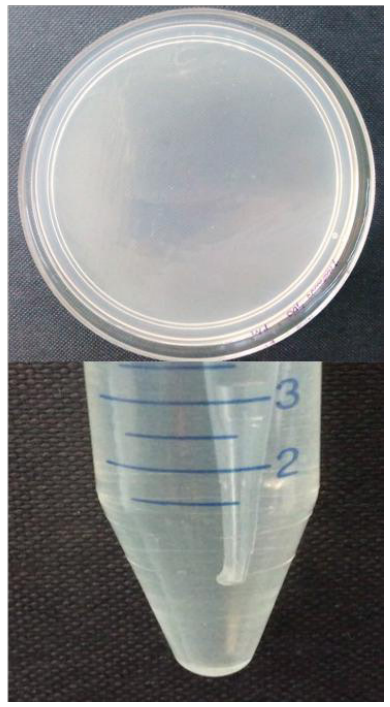

RAJAH 3. Fenotip penghasilan prodigiosin Sma 274 dan Sma WF pada medium yang berlainan Pengkulturan bakteria pada piring agar gliserol pepton dan dalam kaldu PGB selama 24 jam pada suhu $28{ }^{\circ} \mathrm{C}$ menunjukkan (A) Sma 274 menghasilkan koloni berwarna merah dengan prodigiosin manakala (B) Sma WF menghasilkan koloni berlutsinar tanpa prodigiosin. Pengkulturan pada piring agar M9 dan dalam kaldu M9 menunjukkan (C) Sma 274 dan (D) Sma WF menghasilkan koloni yang sangat kecil dan tiada tanda kekeruhan diperhatikan selepas pengeraman selama 96 jam pada suhu $28^{\circ} \mathrm{C}$ 
A
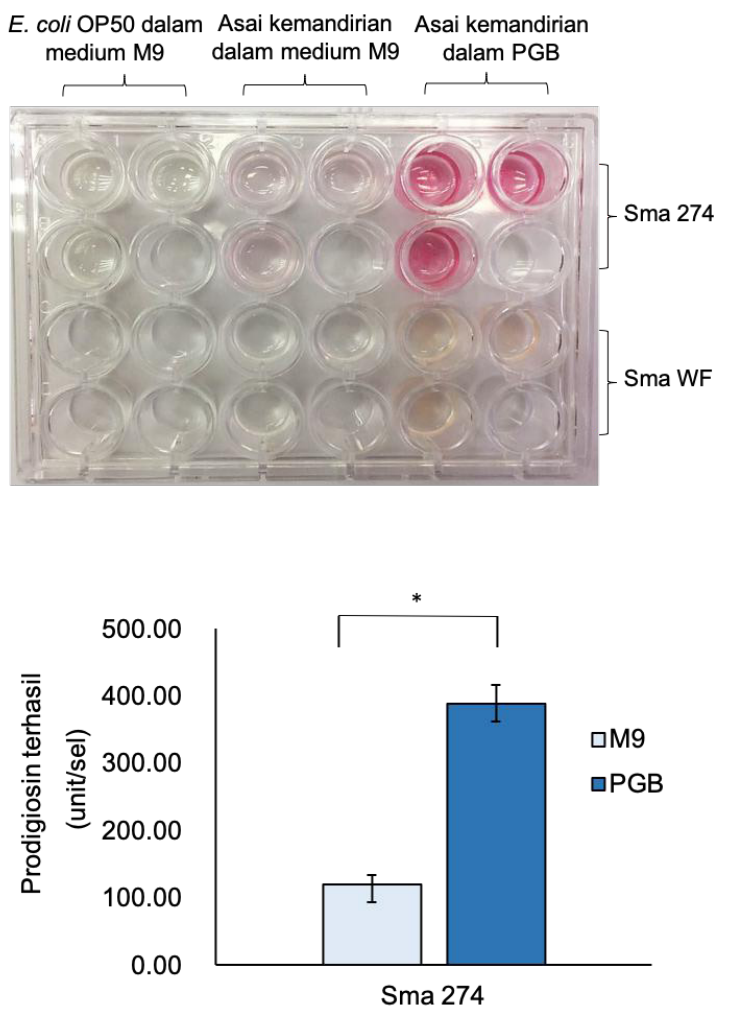

C

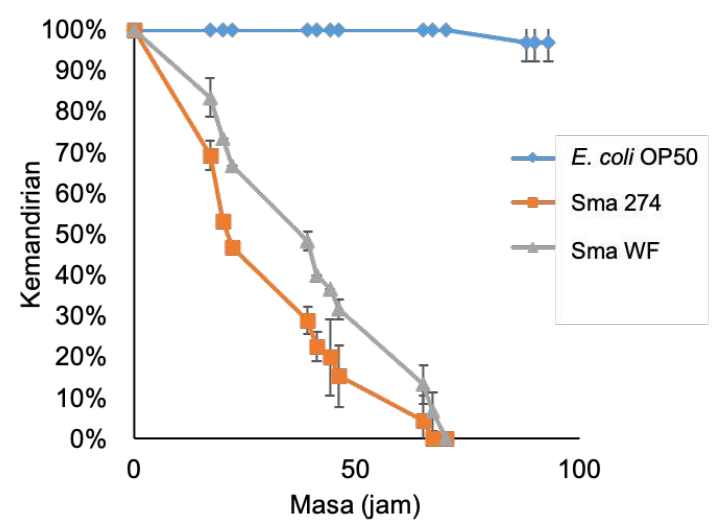

RAJAH 4. Kemandirian C. elegans yang terdedah kepada Sma 274 dan Sma WF di bawah keadaan penghasilan prodigiosin yang telah dioptimumkan

(A) Kemandirian C. elegans yang terdedah kepada Sma 274, Sma WF dan E. coli OP50 dalam piring 24-telaga mengandungi medium yang berlainan. (B) Perbandingan jumlah prodigiosin terhasil di antara bakteria yang dikultur dalam medium M9 dan PGB. (C) Lengkung kemandirian yang dijana daripada infeksi C. elegans dengan Sma 274 dan Sma WF di dalam medium cecair yang terdiri daripada 90\% PGB, 10\% kultur bakteria semalaman (Sma 274 / Sma WF) dan kolesterol pada $28^{\circ} \mathrm{C}$. Sma 274 dan Sma WF didapati membunuh C. elegans di bawah keadaan penghasilan prodigiosin optimum

A

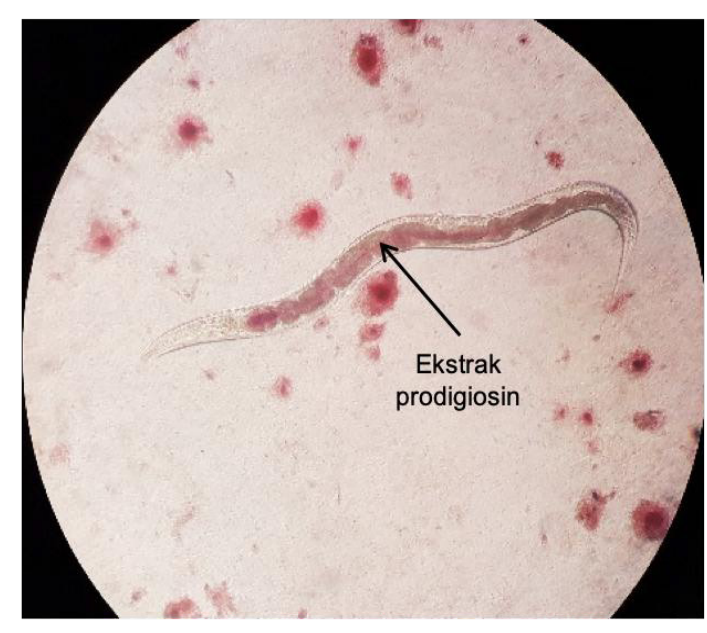

\section{B}

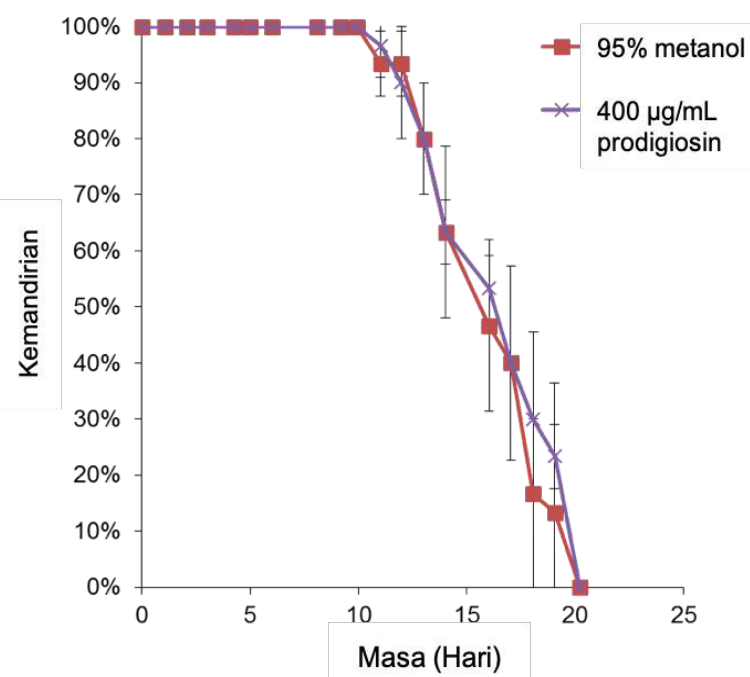

RAJAH 5. Kesan ekstrak prodigiosin terhadap fenotip dan kemandirian C. elegans yang tidak terinfeksi

(A) Pemerhatian C. elegans yang terdedah kepada $400 \mu \mathrm{g} / \mathrm{mL}$ ekstrak prodigiosin di bawah stereomikroskop (Nikon Eclipse TS100) pada pembesaran 200X. (B) Kemandirian C. elegans yang diberikan ekstrak prodigiosin 
JADUAL 1. Analisis Kaplan-Meier C. elegans yang diinfeksi Sma 274 dan Sma WF di bawah keadaan penghasilan prodigiosin optimum

\begin{tabular}{cccc}
\hline Asai kemandirian & Strain bakteria & $\mathrm{TD}_{\min }$ (jam) & $\begin{array}{c}\text { Log-rank } \\
\text { (Mantel-Cox) } \\
\text { Nilai p }\end{array}$ \\
\hline $\begin{array}{c}\text { Keadaan penghasilan prodigiosin yang } \\
\text { optimum } \\
\text { (Medium cecair PGB, pH 7 dan suhu } \\
\text { pengeraman 28 C) }\end{array}$ & Sma 274 & $33.281 \pm 2.182$ & \\
& Sma WF & $41.683 \pm 2.513$ & 0.0070 \\
\hline
\end{tabular}

\section{PERBINCANGAN}

Prodigiosin telah terbukti mempunyai pelbagai ciri yang bermanfaat serta dadah klinikal yang berpotensi tinggi. Untuk menunjukkan yang prodigiosin adalah selamat untuk dibangunkan sebagai dadah klinikal, ketoksikan metabolit ini telah dinilai dalam kajian ini. Pelbagai strain S. marcescens, termasuk yang berpigmen dan tidak berpigmen telah dilaporkan berupaya menginfeksi dan membunuh C. elegans (Kurz et al. 2003). Dalam kajian ini, asai kemandirian cecair $C$. elegans-S. marcescens di bawah keadaan penghasilan prodigiosin tinggi telah dibangunkan. Faktor-faktor luaran seperti jenis medium, suhu dan $\mathrm{pH}$ telah diuji secara berturutan dan didapati mempengaruhi penghasilan prodigiosin. Parameter yang berupaya mendorong penghasilan prodigiosin yang tinggi seterusnya telah digunakan dalam asai kemandirian C. elegans. Hasil kajian ini mendapati bakteria yang dikultur dalam medium PGB menunjukkan penghasilan prodigiosin yang lebih tinggi iaitu 763.55 unit/sel berbanding dengan medium NB yang sebanyak 500.00 unit/sel seperti yang diperoleh dalam kajian terdahulu (Giri et al. 2004; Gulani et al. 2012). Kaldu PGB telah ditunjukkan berupaya menghasilkan jumlah prodigiosin yang lebih tinggi berbanding dengan medium sintetik lain seperti LB, ekstrak malt, ekstrak yis tripton, tripton soya dan ekstrak gliserol (Gulani et al. 2012). Selain itu, hasil kajian ini juga adalah konsisten dengan kajian terdahulu yang menunjukkan penghasilan prodigiosin adalah optimum pada pH 7 (Jafarzade et al. 2013; Pradeep et al. 2013; Ramani et al. 2014).

Kajian terdahulu telah menunjukkan bahawa medium M9 adalah medium yang biasa digunakan dalam asai kemandirin cecair C. elegans dan asai jangka hayat (Bansal et al. 2015; Eng \& Nathan 2015; Kong et al. 2014). Dalam kajian ini, ujian kemandirian $C$. elegans yang berasaskan penghasilan prodigiosin maksimum telah dilakukan di bawah parameter penghasilan prodigiosin optimum yang telah dikenal pasti. Medium PGB terdiri daripada pepton dan gliserol manakala medium M9 hanya mengandungi garam seperti kalium dihidrogen fosfat, disodium hidrogen fosfat, natrium klorida dan magnesium sulfat. Pepton dalam kaldu PGB adalah bahan pencernaan protein tumbuhan dan haiwan dan membekalkan unsur penting seperti peptida dan asid amino untuk memenuhi keperluan nitrogen, sulfur, karbon dan tenaga organisma. Oleh itu, kehadiran pepton dalam medium adalah penting untuk menggalakkan proliferasi sel bakteria dan seterusnya penghasilan prodigiosin. Selain itu, gliserol dalam medium pengkulturan bakteria juga merupakan sumber karbon yang penting untuk mendorong pertumbuhan sel dan penghasilan prodigiosin (Hejazi et al. 1997).

Kami pernah melaporkan bahawa $C$. elegans yang diinfeksi dengan Sma 274 dan Sma WF yang dihidupkan pada NGM yang berasaskan agar menunjukkan tingkah laku pengelakan laman bakteria (Seah et al. 2016). Cacing nematod mempunyai kecenderungan untuk menghindari laman bakteria dan kekal di sekeliling pinggir laman bakteria. Akibatnya, pendedahan $C$. elegans terhadap bakteria adalah terhad dan $C$. elegans tidak terdedah sepenuhnya kepada prodigiosin. Pengelakan laman bakteria berlaku disebabkan tingkah laku dwifasa bakteria patogen tertentu yang berupaya menyebabkan C. elegans memasuki laman bakteria dan keluar semula (Pujol et al. 2001). Fenomena ini disokong oleh Pradel et al. (2007) yang menunjukkan bahawa C. elegans menunjukkan tingkah laku pengelakan terhadap laman bakteria $S$. marcescens. Serrawetin W2 yang dihasilkan oleh $S$. marcescens Db 11 dicadangkan bertindak sebagai faktor yang menyebabkan C. elegans menunjukkan tingkah laku tersebut. Oleh yang demikian, dalam kajian ini, kami menambahbaik asai ini dengan menggunakan ujian kemandirian $C$. elegans yang berasaskan cecair supaya cacing nematod terendam dalam kultur homogen S. marcescens. Melalui pendekatan ini, cacing nematod terdedah sepenuhnya kepada prodigiosin yang dirembeskan.

Hasil asai kemandirian cecair C. elegans-S. marcescens yang berasaskan penghasilan prodigiosin maksimum menunjukkan bahawa perbezaan nilai $\mathrm{TD}_{\min }$ adalah tidak signifikan di antara kedua-dua strain S. marcescens (Ujian Log-rank (Mantel-Cox), p> 0.0001). Di samping itu, kinetik pembunuhan cacing nematod yang diperhatikan melalui hasil ujian kemandirian yang berasaskan cecair dan agar juga tidak menunjukkan perbezaan yang signifikan, sejajar dengan hasil kajian kami yang terdahulu (Seah et al. 2016). Oleh itu, penemuan ini menunjukkan bahawa prodigiosin adalah metabolit yang tidak berbahaya dan tidak mempunyai 
kesan ketoksikan yang ketara terhadap cacing nematod. Ini juga disokong oleh Wilf dan Salmond (2012) yang melaporkan peningkatan penghasilan prodigiosin oleh mutan Serratia sp. ATCC39006-rpoS juga tidak virulen terhadap C. elegans. Oleh itu, kemungkinan besar terdapat faktor lain yang dirembes oleh $S$. marcescens yang mampu membunuh C. elegans tanpa bergantung kepada keupayaan bakteria untuk menghasilkan pigmen. Beberapa enzim seperti kitinase dan lipase kloroperoksidase, serta protein ekstrasel, HasA telah dilaporkan sebagai faktor kevirulenan S. marcescens (Hejazi et al. 1997). Di samping itu, Kurz et al. (2003) juga mendedahkan bahawa protein yang terlibat dalam proses pengambilan ferum, penghasilan hemolisin dan biosintesis lipopolisakarida (LPS) diperlukan untuk kevirulenan in vivo penuh $\mathrm{S}$. marcescens dalam C. elegans. Oleh itu, protein-protein tersebut mungkin merupakan faktor kevirulenan utama yang menyebabkan pembunuhan cacing nematod tetapi bukan prodigiosin.

Selanjutnya, untuk mengesahkan jika prodigiosin adalah selamat untuk dibangunkan sebagai dadah klinikal, ujian ketoksikan telah dilakukan dengan mendedahkan C. elegans kepada prodigiosin yang telah diekstrak. Dalam ujian ketoksikan ini, C. elegans yang terdedah kepada ekstrak prodigiosin tidak menunjukkan sebarang tanda ketoksikan kerana kadar kemandirian cacing nematod yang dirawat dengan ekstrak prodigiosin tidak berbeza berbanding dengan kadar kemandirian cacing normal. Hasil kajian ini adalah sejajar dengan kajian terdahulu yang menunjukkan bahawa prodigiosin tidak memperlihatkan tanda-tanda ketoksikan semasa rawatan untuk penyakit cedung-lawan-perumah dalam model tetikus (Han et al. 2005). Selain itu, prodigiosin tulen juga tidak memberi kesan genotoksik pada tikus kerana bilangan mikronuklei dalam eritrosit polikromik didapati tidak menunjukkan perbezaan yang ketara berbanding dengan kawalan negatif(Guryanov et al. 2013). Kalesperis et al. (1975) juga melaporkan bahawa prodigiosin yang diekstrak dengan asid asetik glasial tidak menyebabkan ketaknormalan dalam embrio ayam. Kesemua keputusan ini menyokong penemuan kajian ini yang menunjukkan bahawa prodigiosin tidak menyumbang kepada ketoksikan dalam organisma model yang diuji.

\section{KESIMPULAN}

Dalam kajian ini, asai kemandirian cecair yang berasaskan kepada keadaan penghasilan prodigiosin yang tinggi telah berjaya dibangunkan. Hasil asai kemandirian menunjukkan bahawa kinetik pembunuhan C. elegans oleh $S$. marcescens yang menghasilkan prodigiosin dan tidak menghasilkan prodigiosin adalah tidak berbeza. Di samping itu, hasil asai ketoksikan menunjukkan bahawa prodigiosin yang diekstrak juga tidak mempamerkan sebarang kesan negatif terhadap jangka hayat C. elegans. Hasil kajian ini membuktikan yang prodigiosin adalah tidak toksik terhadap perumahnya dan mencadangkan sebatian semula jadi ini sebagai dadah yang berpotensi tinggi untuk dibangunkan sebagai sebatian farmaseutik.

\section{PENGHARGAAN}

Kajian ini dibiayai melalui geran penyelidikan Universiti Kebangsaan Malaysia (ICONIC-2013-004). Penghargaan turut dirakamkan kepada Kementerian Pengajian Tinggi Malaysia untuk biasiswa MyBrain15 yang diterima oleh Siew-Wei Seah.

RUJUKAN

Alegado, R.A., Campbell, M.C., Chen, W.C., Slutz, S.S. \& Tan, M.W. 2003. Characterization of mediators of microbial virulence and innate immunity using the Caenorhabditis elegans host-pathogen model. Cellular Microbiology 5(7): 435-444.

Allen, E.G. 1967. Conditions of the colour change of prodigiosin. Nature 216: 929-931.

Bansal, A., Zhu, L.J., Yen, K. \& Tissenbaum, H.A. 2015. Uncoupling lifespan and healthspan in Caenorhabditis elegans longevity mutants. Proceedings of the National Academy of Sciences of the United States of America 112(3): E277-E286.

de Araújo, H.W., Fukushima, K. \& Takaki, G.M. 2010. Prodigiosin production by Serratia marcescens UCP 1549 using renewable-resources as low cost substrate. Molecules 15: 6931-6940.

Deorukhkar, A.A., Chander, R., Ghosh, S.B. \& Sainis, K.B. 2007. Identification of a red-pigmented bacterium producing a potent anti-tumor N-alkylated prodigiosin as Serratia marcescens. Research in Microbiology 158(5): 399-404.

Eng, S.A. \& Nathan, S. 2015. Curcumin rescues Caenorhabditis elegans from a Burkholderia pseudomallei infection. Frontiers in Microbiology 6: 290.

Garsin, D.A., Sifri, C.D., Mylonakis, E., Qin, X., Singh, K.V., Murray, B.E., Calderwood, S.B. \& Ausubel, F.M. 2001. A simple model host for identifying Gram-positive virulence factors. Proceedings of the National Academy of Sciences of the United States of America 98(19): 10892-10897.

Giri, A.V., Anandkumar, N., Muthukumaran, G. \& Pennathur, G. 2004. A novel medium for the enhanced cell growth and production of prodigiosin from Serratia marcescens isolated from soil. BMC Microbiology 4: 1-10.

Gulani, C., Bhattacharya, S. \& Das, A. 2012. Assessment of process parameters influencing the enhanced production of prodigiosin from Serratia marcescens and evaluation of its antimicrobial, antioxidant and dyeing potentials. Malaysian Journal of Microbiology 8(2): 116-122.

Guryanov, I.D., Karamova, N.S., Yusupova, D.V., Gnezdilov, O.I. \& Koshkarova, L.A. 2013. Bacterial pigment prodigiosin and its genotoxic effect. Russian Journal of Bioorganic Chemistry 39: 106-111.

Haddix, P.L. \& Werner, T.F. 2000. Spectrophotometric assay of gene expression: Serratia marcescens pigmentation. Bioscene 26: 3-13.

Han, S.B., Chang, W.L., Yeo, D.Y., Jong, S.K., Ki, H.L., Won, K.Y., Young, K.K., Lee, K., Park, S.K. \& Kim, H.M. 2005. Effective prevention of lethal acute graft-versus-host disease by combined immunosuppressive therapy with prodigiosin and cyclosporine A. Biochemical Pharmacology 70(10): 1518-1526. 
Harvey, A.L. 2008. Natural products in drug discovery. Drug Discovery Today 13(19): 894-901.

Hejazi, A., Falkiner, F.R., Microbiology, C., College, T., Patrick, S. \& James, S. 1997. Serratia marcescens. Journal of Medical Microbiology 46(11): 903-912.

Hunt, P.R. 2017. The C. elegans model in toxicity testing. Journal of Applied Toxicology 37(1): 50-59.

Irazoqui, J.E., Urbach, J.M. \& Ausubel, F.M. 2010. Evolution of host innate defence: Insights from Caenorhabditis elegans and primitive invertebrates. Nature Reviews Immunology 10(1): 47-58.

Jafarzade, M., Yahya, N.A., Shayesteh, F., Usup, G. \& Ahmad, A. 2013. Influence of culture conditions and medium composition on the production of antibacterial compounds by marine Serratia sp. WPRA3. Journal of Microbiology 51(3): 373-379.

Kalesperis, G.S., Prahlad, K.V. \& Lynch, D.L. 1975. Toxigenic studies with the antibiotic pigments from Serratia marcescens. Canadian Journal of Microbiology 21(2): 213-220.

Kavitha, R., Aiswariya, S. \& Ratnavali, C.M.G. 2010. Anticancer activity of red pigment from Serratia marcescens in human cervix carcinoma. International Journal of PharmTech Research 2(1): 784-787.

Koehn, F.E. \& Carter, G.T. 2005. The evolving role of natural products in drug discovery. Nature Reviews Drug Discovery 4(3): 206-220.

Kong, C., Eng, S.A., Lim, M.P. \& Nathan, S. 2016. Beyond traditional antimicrobials: A Caenorhabditis elegans model for discovery of novel anti-infectives. Frontiers in Microbiology 7: 1956.

Kong, C., Yehye, W.A., Abd Rahman, N., Tan, M.W. \& Nathan, S. 2014. Discovery of potential anti-infectives against Staphylococcus aureus using a Caenorhabditis elegans infection model. BMC Complementary and Alternative Medicine 14(1): 4.

Kurz, C.L., Chauvet, S., Andrès, E., Aurouze, M., Vallet, I., Michel, G.P.F., Uh, M., Celli, J., Filloux, A., De Bentzmann, S., Steinmetz, I., Hoffmann, J.A., Finlay, B.B., Gorvel, J.P., Ferrandon, D. \& Ewbank, J.J. 2003. Virulence factors of the human opportunistic pathogen Serratia marcescens identified by in vivo screening. EMBO Journal 22(7): 14511460 .

Mallo, G.V., Kurz, C.L., Couillault, C., Pujol, N., Granjeaud, S., Kohara, Y. \& Ewbank, J.J. 2002. Inducible antibacterial defense system in C. elegans. Current Biology 12(14): 1209-1214.

Nakashima, T., Kurachi, M., Kato, Y., Yamaguchi, K. \& Oda, T. 2005. Characterization of bacterium isolated from the sediment at coastal area of Omura Bay in Japan and several biological activities of pigment produced by this isolate. Microbiology and Immunology 49(5): 407-415.

Pradeep, B.V., Pradeep, F.S., Angayarkanni, J. \& Palaniswamy, M. 2013. Optimization and production of prodigiosin from Serratia marcescens MBB05 using various natural substrates. Asian Journal of Pharmaceutical and Clinical Research 6(1): 34-41.

Pradel, E., Zhang, Y., Pujol, N., Matsuyama, T., Bargmann, C.I. \& Ewbank, J.J. 2007. Detection and avoidance of a natural product from the pathogenic bacterium Serratia marcescens by Caenorhabditis elegans. Proceedings of the National Academy of Sciences of the United States of America 104(7): 2295-2300.
Pujol, N., Link, E.M., Liu, L.X., Kurz, C.L., Alloing, G., Tan, M.W., Ray, K.P., Solari, R., Johnson, C.D. \& Ewbank, J.J. 2001. A reverse genetic analysis of components of the Toll signaling pathway in Caenorhabditis elegans. Current Biology 11(11): 809-821.

Ramani, D.G., Nair, A. \& Krithika, K. 2014. Optimization of cultural conditions for the production of prodigiosin by Serratia marcescens and screening for the antimicrobial activity of prodigiosin. International Journal of Pharma and Bio Sciences 5(3): 383-392.

Seah, S.W., Nathan, S. \& Wan, K.L. 2016. Toxicity evaluation of prodigiosin from Serratia marcescens in a Caenorhabditis elegans model. AIP Conference Proceedings 1784(1): 020015.

Shapira, M. \& Tan, M.W. 2008. Genetic analysis of Caenorhabditis elegans innate immunity. Dlm. Innate Immunity. Methods in Molecular Biology, disunting oleh Ewbank, J. \& Vivier, E. New Jersey: Humana Press. hlm. 429-442.

Tan, M.W., Rahme, L.G., Sternberg, J.A., Tompkins, R.G. \& Ausubel, F.M. 1999. Pseudomonas aeruginosa killing of Caenorhabditis elegans used to identify $P$. aeruginosa virulence factors. Proceedings of the National Academy of Sciences of the United States of America 96(5): 2408-2413.

Webb, D. \& Jamison, T.F. 2010. Continuous flow multi-step organic synthesis. Chemical Science 1(6): 675.

Wilf, N.M. \& Salmond, G.P.C. 2012. The stationary phase sigma factor, RpoS, regulates the production of a carbapenem antibiotic, a bioactive prodigiosin and virulence in the enterobacterial pathogen Serratia sp. ATCC 39006. Microbiology 158(3): 648-658.

Yip, C.H., Yarkoni, O., Ajioka, J., Wan, K.L. \& Nathan, S. 2019. Recent advancements in high-level synthesis of the promising clinical drug, prodigiosin. Applied Microbiology \& Biotechnology 104: 1667-1680

Siew-Wei Seah, Sheila Nathan \& Kiew-Lian Wan*

Pusat Bioteknologi dan Makanan Berfungsi

Fakulti Sains dan Teknologi

Universiti Kebangsaan Malaysia

43600 UKM Bangi, Selangor Darul Ehsan

Malaysia

Siew-Wei Seah, Nur Siti Fatimah Mohamad Jamil, Yann-Yin Lee, Cin Kong, Sheila Nathan \& Kiew-Lian Wan*

Pusat Pengajian Biosains dan Bioteknologi

Fakulti Sains dan Teknologi

Universiti Kebangsaan Malaysia

43600 UKM Bangi, Selangor Darul Ehsan

Malaysia

Cin Kong

Jabatan Sains Bioperubatan

Fakulti Sains

Kampus Universiti Nottingham Malaysia

43500 Semenyih, Selangor Darul Ehsan

Malaysia

*Pengarang untuk surat-menyurat; email: klwan@ukm.edu.my

Diserahkan: 18 Jun 2019

Diterima: 18 Disember 2019 